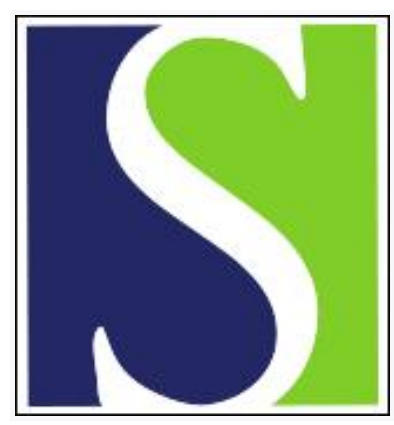

Scand J Work Environ Health 1993;19(3):175-182

https://doi.org/10.5271/sjweh.1484

Issue date: 01 Jun 1993

Urinary styrene in the biological monitoring of styrene exposure.

by Gobba F, Galassi C, Ghittori S, Imbriani M, Pugliese F, Cavalleri A

Affiliation: Cattedra di Medicina del Lavoro, Universita di Modena, Italy.

This article in PubMed: www.ncbi.nlm.nih.gov/pubmed/8367695

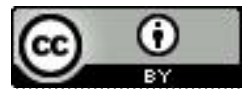




\title{
Urinary styrene in the biological monitoring of styrene exposure
}

\author{
by Fabriziomaria Gobba, MD, ${ }^{1}$ Claudia Galassi, MD, ${ }^{1}$ Sergio Ghittori, BS, ${ }^{2}$ \\ Marcello Imbriani, MD, ${ }^{3}$ Franco Pugliese, MD, ${ }^{4}$ Alessandro Cavalleri, MD
}

\begin{abstract}
GOBBA F, GALASSI C, GHITTORI S, IMBRIANI M, PUGLIESE F, CAVALLERI A. Urinary styrene in the biological monitoring of styrene exposure. Scand J Work Environ Health 1993;19:17582. The urinary excretion of styrene represents a promising indicator of exposure to this solvent. Nevertheless extensive research under field conditions is scant. In this investigation 214 styrene-exposed workers from 10 fiberglass-reinforced plastics factories were studied. Environmental monitoring was performed by personal passive sampling. Blood styrene and the urinary excretion of styrene and its main metabolites, mandelic acid (MA) and phenylglyoxylic acid (PGA), were measured. The correlation coefficient between the time-weighted average of environmental styrene and the mean urinary excretion of styrene was 0.88 ( 0.91 after logarithmic transformation), compared with the 0.82 and 0.78 of the end-of-shift MA and PGA values, respectively. A high correlation (0.86) was also found between styrene in the blood and urine. The results, obtained under field conditions with a large group of exposed workers, confirm the usefulness of the urinary excretion of styrene as an exposure index for the biological monitoring of styrene exposure.
\end{abstract}

Key terms: biological equivalent exposure limit, biological exposure index, glass-reinforced plastics, styrene metabolites.

Currently styrene exposure is biologically monitored from measurements of the urinary excretion of mandelic acid (MA) and phenylglyoxylic acid (PGA), the two main metabolites of styrene (1). Nevertheless, the monitoring procedures have yet to be agreed upon. Some authors recommend measuring MA, or calculating the sum of the measurements of MA and PGA, at the end of the workshift, while others propose end-of-shift PGA or the sum of the MA and PGA in samples collected $16 \mathrm{~h}$ after exposure (next morning) (1). There is no agreement on the biological limits either. For example, for end-of-shift MA the American Conference of Governmental Industrial Hygienists (ACGIH) proposes a biological exposure index of $800 \mathrm{mg} \cdot \mathrm{g}^{-1}$ of creatinine (2), while the proposed Deutsche Forschungsgemeinschaft (DFG) limit [biological tolerance values for working materials

Cattedra di Medicina del Lavoro, Universita' di Modena (Chair of Occupational Medicine, University of Modena), Modena, Italy.

2 Fondazione Clinica del Lavoro, Centro Medico di Pavia ("Clinica del Lavoro" Foundation, Medical Center of Pavia), Pavia, Italy.

3 Dipartimento Medicina Preventiva, Occupazionale e di Comunita', Universita' di Pavia (Department of Preventive, Occupational and Community Medicine, University of Pavia), Pavia, Italy.

4 Servizio di Medicina del Lavoro, Unità Sanitaria Locale N.2 (Occupational Health Service, Local Health Unit N.2), Piacenza, Italy.

5 Sezione di Medicina Preventiva dei Lavoratori, Università di Pavia (Section of Preventive Medicine of Workers, University of Pavia), Pavia, Italy.

Reprint requests to: Dr F Gobba, Cattedra di Medicina del Lavoro, Universita' di Modena, Via Campi 287, I-41100 Modena, Italy.
(BAT)] is $2 \mathrm{~g} \cdot \mathrm{l}^{-1}$ (3). Other exposure tests, such as styrene in expired air $(4-7)$ or in blood $(8-10)$, present some limitations, and available data on field application are limited (1). Finally, the measurement of minor metabolites, such as hippuric acid or 4-vinylphenol, is still not considered reliable.

Another problem in the biological monitoring of styrene exposure is the large interindividual variability caused for MA and PGA excretion by factors such as nonspecificity of the two metabolites, interference from other solvents, drugs and alcohol consumption, differences in individual metabolism, and the like $(1,11)$. An index proposed for the biological monitoring of styrene exposure that possibly avoids some of the cited problems is the measurement of the urinary excretion of the solvent $(12,13)$. Urinary styrene, like the urinary metabolites, mainly represents a weighted index of exposure, while the concentrations of the solvent in alveolar air represent instantaneous values (14).

Some preliminary data suggest that this index is reliable in predicting styrene exposure, the correlation coefficient between airborne styrene levels and urinary excretion varying between 0.88 for field conditions and 0.93 for volunteers $(1,14)$. Moreover this test is specific and seems to be hardly affected by other solvents interfering in the biotransformation rate or by the presence of common metabolites (14). After considering these preliminary data, we decided to study urinary styrene excretion in a group of workers from different factories producing products made of fiberglass-reinforced plastics. Our goal was to define, under field conditions, the usefulness of urinary styrene as an index of occupational exposure to styrene. 


\section{Materials and methods}

Subjects

Two hundred and fourteen workers (114 men and 100 women), mean age 28.1 ( $S D=10.6$ ) years, from 10 fiberglass-reinforced plastics factories were examined. The workers were engaged in the hand production of products of various shapes and dimensions.

Information on the workers' health status, smoking habits, and alcohol consumption was collected by means of a questionnaire during a medical examination. All of the workers were apparently healthy, and the daily average consumption of ethanol was always less than $50 \mathrm{~g}$.

\section{Environmental air sampling}

For each examined worker, exposure was measured in their breathing zone with personal passive dosimeters (TK 200 Zambelli). Airborne styrene levels were determined on Thursday. This day was selected because the workers in several of the factories were engaged in the maintenance of plants on Friday (the last workday of the week, considered in various other studies), and therefore the exposure was not comparable with other days for aspects like quantity of styrene handled, work load, use of acetone, and the like.

A whole workshift $(8 \mathrm{~h})$ was evaluated. Morning and afternoon half shifts were monitored separately, each sampling period lasting $4 \mathrm{~h}$. The only other solvent used in the workplaces was acetone. Nevertheless its environmental concentrations were always low, never exceeding $500 \mathrm{mg} \cdot \mathrm{m}^{-3}$.

\section{Biological monitoring}

On the same day of the environmental monitoring, at 0800 , all of the workers were asked to empty their bladder. Then at 1200 (end of the first half shift) a sample of urine was collected. At 1300 the subjects emptied their bladder once more, and a specimen was again obtained at 1700 (end of shift).

Only urine samples of the whole half shifts (from 0800 to 1200 and from 1300 to 1700 , respectively) were considered. If the workers had to urinate during a half shift, the sample was discarded. Five samples from the morning and 10 from the afternoon were excluded from the study for this reason.

Within 2 min of the voiding, in an atmosphere not polluted by styrene, $10 \mathrm{ml}$ of the urine samples was transferred to 120 -ml glass vials (Supelco Vials) with airtight plugs without silicone and kept refrigerated until the analysis.

For 100 of these workers, $5 \mathrm{ml}$ of venous blood was collected from a brachial vein at the end of the morning shift, 10 to 15 min after the end of the styrene exposure. The samples were immediately injected into heparinized glass vials as described for urinary styrene.
For a smaller group of 65 workers MA, PGA, and styrene were measured in urine samples collected at the end of the shift and at 0800 on Friday (next morning sample). This subgroup was fully comparable to the total group in all relevant aspects (age, gender distribution, ethanol consumption, type and entity of exposure, work load, etc).

\section{Analytical methods}

Styrene was measured by a gas chromatograph (HP $5880 \mathrm{~A}$ ) connected to a mass selective detector (HP 5970 A). Details on the analytical methods have been reported elsewhere (14).

The activated charcoal of passive dosimeters was desorbed with $5 \mathrm{ml}$ of carbon disulfide and kept at room temperature $\left(20^{\circ} \mathrm{C}\right)$ for $1 \mathrm{~h}$, during which it was periodically shaken. Desorption liquid $(0.5 \mathrm{ml})$ was injected into the gas chromatograph-mass selective detection unit. Vials containing urine (or blood) were stored in a refrigerator $\left(4^{\circ} \mathrm{C}\right)$ until the analysis, which was always performed within a few days. For $2 \mathrm{~h}$ before the analysis the vials were kept at $37^{\circ} \mathrm{C}$ and periodically shaken to speed the separation ad equilibrium of the styrene vapor between the urine or blood and the headspace air.

Two milliliters of the headspace of the vials was then injected ( $2 \mathrm{ml}$ gastight syringe Hamilton) into a $0.5-\mathrm{ml}$ loop of the gas chromatograph.

Urine samples for the MA and PGA measurements were kept frozen until the analysis by a gas chromatographic method (15).

The detection limit of the technique was 0.0048 $\mu \mathrm{mol} \cdot \mathrm{l}^{-1}$. The mean recovery at three different styrene concentrations ranged from 94 to $103 \%$. The interassay coefficient of variation for styrene was $4.2 \%$ (for 10 determinations), the mean value being $1022 \mu \mathrm{mol} \cdot \mathrm{l}^{-1}$. Some volatile chemicals, such as styrene, appear to be eliminated in the kidney by a diffusion process determined by the equilibration of partial pressures in urine and plasma (16). As a result, the urine:blood ratio equals the urine-blood distribution coefficient, and the concentration of the determinant in urine is independent of urinary output. Adjusting for creatinine does not seem to be justified if the excretion mechanism of the determinant differs from the excretion mechanism of creatinine (17); therefore our urinary styrene data are presented without correction. Also for the urinary styrene metabolites (MA and PGA), the results were not corrected as, according to some authors $(18,19)$, an adjustment for variations in urine flow using density or creatinine seems to offer no definite advantages.

\section{Statistical analysis}

All of the statistical analyses were performed with the SPSS-PC $+{ }^{\mathrm{TM}}$ software of the statistical package for the social sciences. A simple linear regression was performed with environmental styrene as the independent variable and urinary styrene or its urinary 
metabolites as the dependent variables. The confidence limits were calculated for the expected values of the dependent variable.

\section{Results}

The results of the environmental and biological monitoring are summarized in table 1. For the whole group, the mean time-weighted (TWA) exposure $\left(843.8 \mu \mathrm{mol} \cdot \mathrm{m}^{-3}\right.$ or $\left.87.9 \mathrm{mg} \cdot \mathrm{m}^{-3}\right)$ was about onethird of the current threshold limit value (TLV), as the TWA, proposed by ACGIH $\left(213 \mathrm{mg} \cdot \mathrm{m}^{-3}\right.$ or $2044.931 \mu \mathrm{mol} \cdot \mathrm{m}^{-3}$ ), but the range of the values varied from 23 up to $7397 \mu \mathrm{mol} \cdot \mathrm{m}^{-3}$. Correspondingly, a wide variation was observed also for the styrene concentration of the urine and blood. Exposure during the morning and afternoon shifts was similar.

The correlation coefficients (r) between airborne styrene and urinary styrene are presented in table 2 ; the corresponding equations are reported in figures $1-4$. We have considered both the relationship between each half-shift exposure and the corresponding urinary styrene values (morning exposure versus urinary styrene at 1200 and afternoon exposure versus urinary styrene at 1700 , respectively) (figures 1 and 2), and 8-h TWA exposure versus mean urinary styrene levels (urinary styrene at 1200 + urinary styrene at 1700/2) (figure 3). In every case the correlation coefficients ranged from 0.82 to 0.88 .

Since the distribution of both the environmental and biological values was fairly skewed, a logarithmic transformation of the variables was performed. A slight increase in the correlation coefficients was observed, as shown in table 2 . The correlation coefficient between the environmental and blood styrene concentrations was also high $(\mathrm{r}=0.86 ; 0.89$ after logarithmic transformation) (table 2). Remarkably, the urinary excretion of styrene (1200 samples) was strictly related $(r=0.86)$ to the blood styrene values obtained at the same time (figure 4 ). The results of the environmental and biological monitoring performed in the subgroup of 65 workers are reported in table 3 .

Tables 4 and 5 show the correlation coefficients and the regression equations between airborne styrene and the exposure indices. The correlation coefficients for urinary styrene were close to those observed for the whole group. MA and PGA in the urine samples taken at the end of the shift correlated better with the styrene exposure $(r=0.82$ and 0.78 , respectively) than the values obtained the next

Table 1. Results of the environmental and biological monitoring. (GM = geometric mean, $G S D=$ geometric standard deviation)

\begin{tabular}{|c|c|c|c|c|c|c|c|c|c|c|c|c|}
\hline \multirow[b]{3}{*}{$\begin{array}{l}\text { Morning half shift } \\
(0800-1200)\end{array}$} & \multicolumn{4}{|c|}{ Airborne styrene levels $\left(\mu \mathrm{mol} \cdot \mathrm{m}^{-3}\right)$} & \multicolumn{4}{|c|}{ Urinary styrene $\left(\mathrm{nmol} \cdot \mathrm{I}^{-1}\right)$} & \multicolumn{4}{|c|}{ Blood styrene $\left(\mu \mathrm{mol} \cdot \mathrm{I}^{-1}\right)$} \\
\hline & $\begin{array}{l}\text { Number } \\
\text { of } \\
\text { subjects }\end{array}$ & $\mathrm{GM}$ & GSD & Range & $\begin{array}{l}\text { Number } \\
\text { of } \\
\text { subjects }\end{array}$ & Mean & SD & Range & $\begin{array}{l}\text { Number } \\
\text { of } \\
\text { subjects }\end{array}$ & Mean & SD & Range \\
\hline & 214 & 731.52 & 35.5 & $36.48-8361.6$ & $\cdot$ & $\cdot$ & $\cdot$ & $\cdot$ & $\cdot$ & $\cdot$ & $\cdot$ & $\cdot$ \\
\hline $\begin{array}{l}\text { Afternoon half shift } \\
(1300-1700)\end{array}$ & 211 & 753.6 & 47.8 & $2.9-9419.5$ & $\cdot$ & $\cdot$ & $\cdot$ & · & $\cdot$ & $\cdot$ & $\cdot$ & · \\
\hline Time-weighted average & 211 & 843.84 & 34.9 & $23-7396.8$ & · & . & · & . & . & . & . & . \\
\hline $\begin{array}{l}\text { End of morning half } \\
\text { shift (at 1200) }\end{array}$ & - & $\cdot$ & . & - & 209 & 577.6 & 571.6 & $0-2688$ & 100 & 5.3 & 4.97 & $0.16-20.8$ \\
\hline $\begin{array}{l}\text { End afternoon half shifta } \\
\text { (at } 1700)\end{array}$ & . & . & $\cdot$ & · & 204 & 565.63 & 490.66 & $4.8-2201.3$ & . & $\cdot$ & $\cdot$ & $\cdot$ \\
\hline $\begin{array}{l}\text { End samples (taken at } \\
1200 \text { and } 1700 \text { ) } \\
\text { combined }\end{array}$ & . & $\cdot$ & $\cdot$ & · & 198 & 556.13 & 461.76 & $18.24-2015.04$ & . & - & - & . \\
\hline
\end{tabular}

End of afternoon half shift $=$ end of shift.

Table 2. Correlation coefficients between the airborne styrene levels and the urinary and blood styrene concentrations in the whole group of reinforced plastics workers. (TWA = time-weighted average)

\begin{tabular}{|c|c|c|c|c|c|c|c|}
\hline \multirow[b]{2}{*}{ Index } & \multirow{2}{*}{$\begin{array}{c}\text { Number } \\
\text { of } \\
\text { subjects }\end{array}$} & \multicolumn{6}{|c|}{ Airborne styrene levels } \\
\hline & & \multicolumn{2}{|c|}{$\begin{array}{c}\text { Morning } \\
\text { half shifta } \\
(0800-1200)\end{array}$} & \multicolumn{2}{|c|}{$\begin{array}{c}\text { Afternoon } \\
\text { half shift } \\
(1300-1700)\end{array}$} & \multicolumn{2}{|c|}{ TWAa } \\
\hline of morning half shift & 208 & 0.82 & $(0.89)$ & & $\cdot$ & & . \\
\hline $\begin{array}{l}\text { Urinary styrene concentration, end } \\
\text { of afternoon half shift }{ }^{b}\end{array}$ & 202 & & $\cdot$ & 0.87 & $(0.87)$ & 0.82 & $(0.89)$ \\
\hline Urinary styrene, meanc & 196 & & · & & $\cdot$ & 0.88 & $(0.91)$ \\
\hline Blood styrene, end of morning half shift & 100 & 0.86 & $(0.89)$ & & . & & . \\
\hline
\end{tabular}

a Correlation coefficient after logarithmic transformation of the data in parentheses.

b End of afternoon half shift = end of shift.

c Mean of the morning half-shift and the end-of-shift samples combined. 

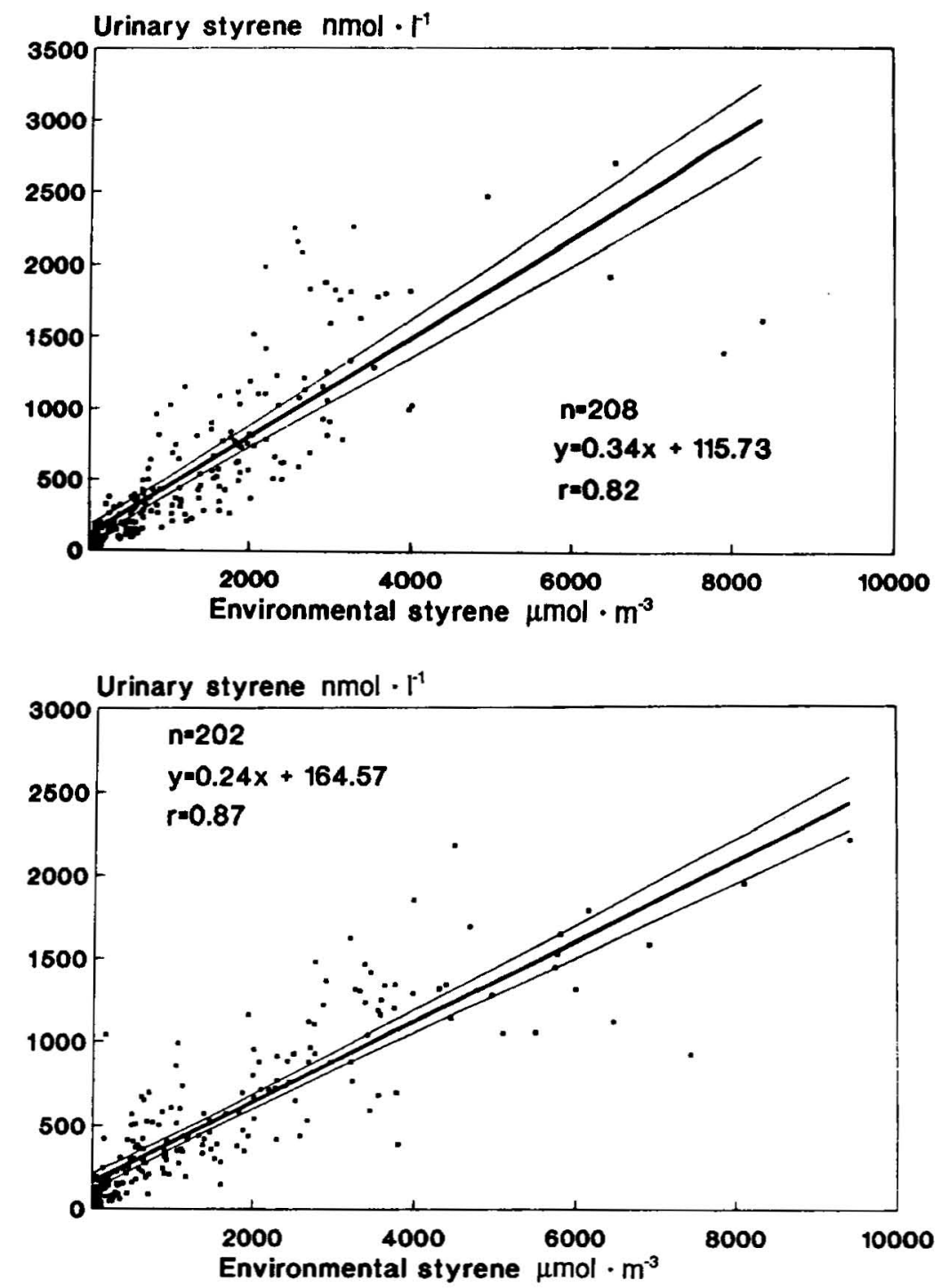

Figure 1. Correlation and $95 \%$ confidence interval for the expected values of $y$ between the morning (0800-1200) level of environmental styrene and the urinary styrene level at 1200.
Figure 2. Correlation and $95 \%$ confidence interval for the expected values of $y$ between the afternoon (1300-1700) level of environmental styrene and the urinary styrene level at 1700 .

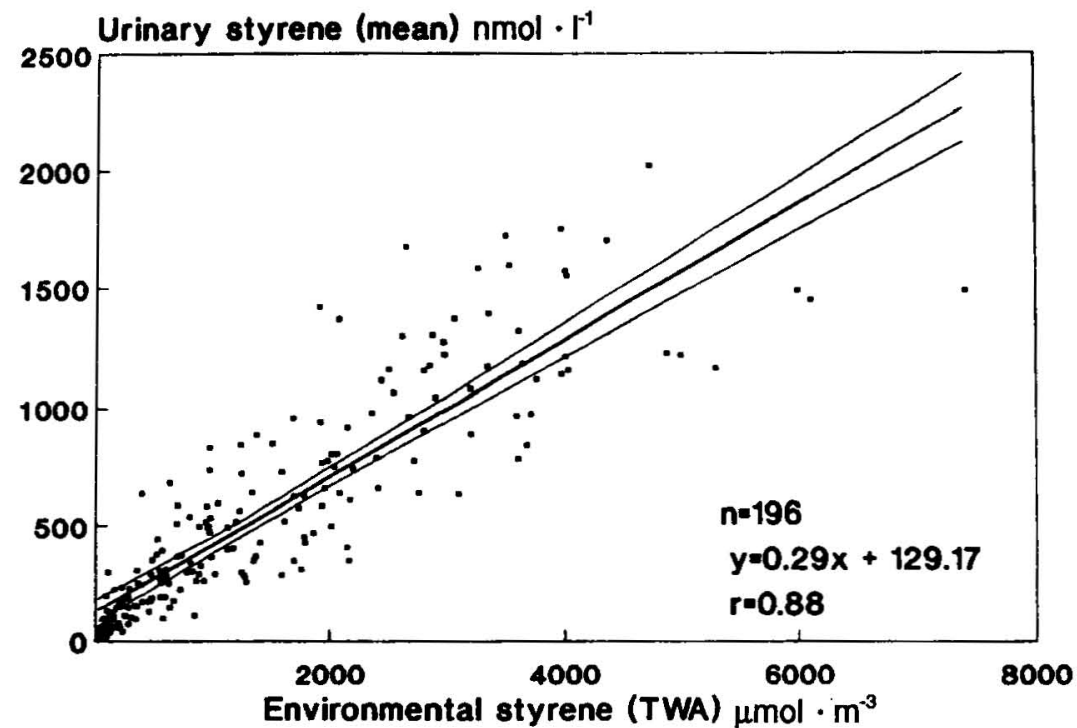

Figure 3. Correlation and $95 \%$ confidence interval for the expected values of $y$ between the time-weighted average (TWA) of the environmental styrene levels (between 0800 and 1700) and the mean urinary styrene level. 
morning ( $r=0.46-0.53$ ). The correlation coefficients between the metabolite concentrations in the samples taken the next morning and the TWA airborne styrene levels were similar to those obtained between the same metabolites and the morning and afternoon environmental concentrations of the solvent (table 4).

\section{Discussion}

Thus far little attention has been paid to gender-related differences in the correlations between environmental styrene levels and exposure indices. For this reason we examined male and female workers separately in a preliminary analysis, but no differences were observed between the two groups. As an example, the regression lines between the TWA environmental levels of styrene and the mean urinary styrene were $\mathrm{y}=0.29 \mathrm{x}+129.7$ and $\mathrm{y}=0.27 \mathrm{x}+154.2$ for the men and women, respectively. The difference was not significant. The same was true for all of the other exposure indices. For this reason, all of the data were pooled in the rest of the analyses.

The observed wide variability in the TWA levels of airborne styrene $\left(20-7400 \mu \mathrm{mol} \cdot \mathrm{m}^{-3}\right)$ is the rule in the reinforced plastics industry, as previously documented (20-22). In the examined group, composed of workers who were exposed to a wide range of styrene levels and who performed different jobs in 10 different factories, we confirmed our preliminary results $(12,23)$. The correlation between environmental styrene and urinary excretion of the solvent was very good, as shown in table 2 and figures $1-3$. The correlation with exposure was of the same order, or possibly better, as those observed for metabolites in

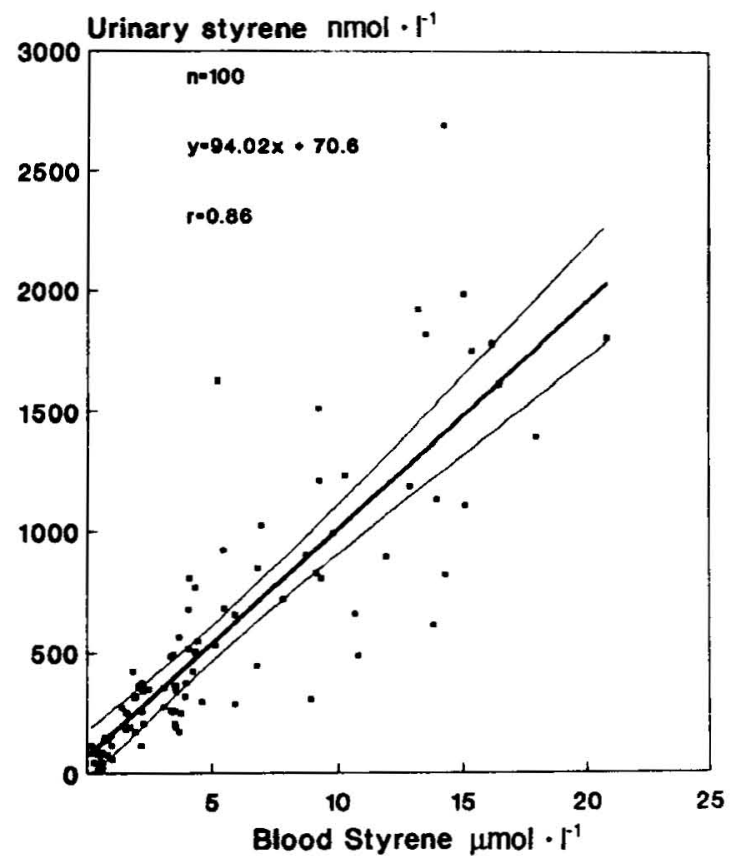

Figure 4. Correlation and $95 \%$ confidence interval for the expected values of $y$ between the styrene levels in blood and urine (samples collected at 1200).

other field studies reported in the literature $(8,10$, 24-26).

Furthermore, the styrene concentrations of the samples collected during each half shift were closely related to the environmental exposure during the same work period. The styrene in the urine sample taken at 1200 represented the morning exposure well, while the styrene in the urine samples taken at 1700

Table 3. Means, standard deviations, and ranges of the exposure indices for the subgroup of 65 reinforced plastics workers. ${ }^{a}$ (TWA = time-weighted average)

\begin{tabular}{|c|c|c|c|c|}
\hline Index & $\begin{array}{l}\text { Number } \\
\text { of } \\
\text { subjects }\end{array}$ & Mean & SD & Range \\
\hline TWA airborne styrene concentration $\left(\mu \mathrm{mol} \cdot \mathrm{m}^{-3}\right)$ & 64 & $1090.4^{a}$ & $30.91^{\mathrm{b}}$ & $76.8-7396.8$ \\
\hline Urinary styrene concentration ( $\mathrm{nmol} \cdot \mathrm{I}^{-1}$ ), end of morning half shift & 62 & 480.58 & 504.19 & $19.2-2688$ \\
\hline Urinary styrene concentration $\left(\left.\mathrm{nmol} \cdot\right|^{-1}\right)$, end of afternoon half shift ${ }^{c}$ & 65 & 605.38 & 515.33 & $38.4-2169.6$ \\
\hline Urinary styrene concentration $\left(\left.\mathrm{nmol} \cdot\right|^{-1}\right)$, meand & 62 & 546.62 & 432.38 & $38.4-1593.6$ \\
\hline Blood styrene concentration $\left(\left.\mu \mathrm{mol} \cdot\right|^{-1}\right)$, end of morning half shift & 36 & 5.65 & 5.24 & $0.48-17.93$ \\
\hline $\begin{array}{l}\text { Urinary mandelic acid concentration }\left(\mathrm{mol} \cdot !^{-1}\right) \text {, } \\
\text { end of afternoon half } \text { shift }^{c}\end{array}$ & 65 & 9.73 & 9.94 & $0.24-40.23$ \\
\hline $\begin{array}{l}\text { Urinary phenylglyoxylic acid concentration }\left(\left.\mathrm{mol} \cdot\right|^{-1}\right) \text {, } \\
\text { end of afternoon half shiftc }\end{array}$ & 65 & 3.30 & 2.82 & $0.07-12.99$ \\
\hline $\begin{array}{l}\text { Sum of urinary phenylglyoxylic acid and mandelic acid concentrations } \\
(\mathrm{mol} \cdot(-1) \text {, end of afternoon half shiftc }\end{array}$ & 65 & 13.03 & 12.76 & $0.31-53.22$ \\
\hline Urinary mandelic acid concentration $\left(\mathrm{mol} \cdot \mathrm{I}^{-1}\right)$, next morning & 58 & 2.64 & 4.22 & $0.07-22.51$ \\
\hline Urinary phenylglyoxylic acid concentration $\left(\left.\mathrm{mol} \cdot\right|^{-1}\right)$, next morning & 58 & 2.24 & 1.92 & $0.07-6.64$ \\
\hline $\begin{array}{l}\text { Sum of urinary phenylglyoxylic acid and mandelic acid } \\
\text { concentrations }(\mathrm{mol} \cdot \mid-1) \text {, next morning }\end{array}$ & 58 & 4.88 & 6.14 & $0.14-29.15$ \\
\hline
\end{tabular}

a Geometric mean.

b Geometric standard deviation.

c End of afternoon half shift = end of shift.

d Mean of the morning half-shift and end-of-shift samples combined. 
Table 4. Correlation coefficients between airborne styrene levels and exposure indices in the selected group of reinforced plas tics workers. (TWA = time-weighted average)

\begin{tabular}{|c|c|c|c|c|c|c|c|}
\hline \multirow{2}{*}{$\begin{array}{l}\text { Urinary styrene concentration }\left(\mathrm{nmol} \cdot \mathrm{I}^{-1}\right) \text {, } \\
\text { end of morning half shift }\end{array}$} & \multirow{2}{*}{$\begin{array}{c}\begin{array}{c}\text { Number } \\
\text { of } \\
\text { subjects }\end{array} \\
62\end{array}$} & \multicolumn{2}{|c|}{$\begin{array}{c}\text { Morning } \\
\text { half shift } \\
(0800-1200)\end{array}$} & \multicolumn{2}{|c|}{$\begin{array}{l}\text { Afternoon } \\
\text { half shift } \\
(1300-1700)\end{array}$} & \multicolumn{2}{|c|}{ TWA $^{a}$} \\
\hline & & 0.88 & $(0.90)$ & & $\cdot$ & & . \\
\hline $\begin{array}{l}\text { Urinary styrene concentration }\left(\mathrm{nmol} \cdot \mathrm{I}^{-1}\right) \\
\text { end of afternoon half } \text { shift }^{\mathrm{b}}\end{array}$ & 65 & & . & 0.86 & $(0.85)$ & & . \\
\hline Urinary styrene concentration $\left(\mathrm{nmol} \cdot \mathrm{I}^{-1}\right)$, meanc & 62 & & . & & . & 0.88 & $(0.89)$ \\
\hline $\begin{array}{l}\text { Blood styrene concentration }\left(\left.\mu \mathrm{mol} \cdot\right|^{-1}\right) \\
\text { end of morning half shift }\end{array}$ & 36 & 0.88 & $(0.92)$ & & - & & $\cdot$ \\
\hline $\begin{array}{l}\text { Urinary mandelic acid concentration }\left(\left.\mathrm{mol} \cdot\right|^{-1}\right) \text {, } \\
\text { end of afternoon half shift }\end{array}$ & 64 & & $\cdot$ & 0.84 & $(0.74)$ & 0.82 & $(0.79)$ \\
\hline $\begin{array}{l}\text { Urinary phenylglyoxylic acid concentration }(\mathrm{mol} \cdot \mid-1) \text {, } \\
\text { end of afternoon half shift }\end{array}$ & 64 & & $\cdot$ & 0.76 & $(0.59)$ & 0.78 & $(0.65)$ \\
\hline $\begin{array}{l}\text { Sum of urinary phenylglyoxylic acid and mandelic } \\
\text { acid concentrations }\left(\left.\mathrm{mol}^{-1} \cdot\right|^{-1}\right) \text {, end of afternoon } \\
\text { half shift }\end{array}$ & 64 & & $\cdot$ & 0.83 & $(0.70)$ & 0.81 & (0.71) \\
\hline $\begin{array}{l}\text { Urinary mandelic acid concentration }\left(\mathrm{mol} \cdot \mathrm{l}^{-1}\right) \text {, } \\
\text { next morning }\end{array}$ & 58 & 0.33 & $(0.60)$ & 0.44 & $(0.64)$ & 0.46 & $(0.68)$ \\
\hline $\begin{array}{l}\text { Urinary phenylglyoxylic acid concentration }(\mathrm{mol} \cdot \mid-1) \text {, } \\
\text { next morning }\end{array}$ & 58 & 0.42 & $(0.54)$ & 0.49 & $(0.58)$ & 0.53 & $(0.62)$ \\
\hline $\begin{array}{l}\text { Sum of urinary phenylglyoxylic acid and mandelic } \\
\text { acid concentrations }\left(\left.\mathrm{mol}^{-1} \cdot\right|^{-1}\right) \text {, next morning }\end{array}$ & 58 & 0.38 & $(0.57)$ & 0.48 & $(0.61)$ & 0.50 & $(0.66)$ \\
\hline
\end{tabular}

a Correlation coefficient after logarithmic transformation of the data in parentheses.

b End of afternoon half shift $=$ end of shift.

c Mean of the morning half shift and the end-of-shift samples combined.

Table 5. Parameters of the regression lines between the environmental styrene concentration and the exposure indices. (TWA = time-weighted average)

\begin{tabular}{lcc}
\hline & Slope & Intercept \\
\cline { 2 - 2 } $\begin{array}{l}\text { Morning urinary concentration of styrene versus morning environmental styrene } \\
\text { concentration }\end{array}$ & 0.26 \\
$\begin{array}{l}\text { End-of-shift concentration of styrene versus afternoon environmental styrene } \\
\text { concentration }\end{array}$ & 0.24 \\
Mean concentration of styrene versus TWA styrene concentration & 0.24 \\
$\begin{array}{l}\text { Morning blood concentration of styrene versus morning environmental styrene } \\
\text { concentration }\end{array}$ & 0.002 \\
$\begin{array}{l}\text { End-of-shift concentration of mandelic acid versus TWA of the environmental } \\
\text { styrene concentration }\end{array}$ & 0.005 \\
$\begin{array}{l}\text { End-of-shift concentration of phenylglyoxylic acid versus TWA of the environmental } \\
\text { styrene concentration }\end{array}$ & 0.001 \\
$\begin{array}{l}\text { Sum of end of shift concentrations of mandelic acid and phenylglyoxylic acid } \\
\text { versus TWA of the environmental styrene concentration }\end{array}$ & 116.22 \\
$\begin{array}{l}\text { Next morning concentration of mandelic acid versus TWA of the environmental } \\
\text { styrene concentration }\end{array}$ & 0.007 \\
$\begin{array}{l}\text { Next morning concentration of phenylglyoxylic acid versus TWA of the environmental } \\
\text { styrene concentration }\end{array}$ & 0.001 \\
$\begin{array}{l}\text { Sum of next morning concentrations of mandelic acid and phenylglyoxylic acid versus } \\
\text { TWA of the, environmental styrene concentration }\end{array}$ & 0.122 .72 \\
\hline
\end{tabular}

a Mean of the morning half-shift and end-of-shift samples combined.

represented the afternoon exposure well. For an evaluation of the exposure during the whole shift, the mean of the urinary styrene excretion at 1200 and 1700 must be considered (table 2, figures $1-3$ ).

As observed by others for metabolites (26-28), also for urinary styrene, the logarithmic transformation of data further improved the correlation coefficient. As an example, the correlation was increased from 0.88 to 0.91 for the relation between the TWA exposure and the urinary styrene concentration (table 2).

The regression line between the exposure and the urinary styrene levels did not start from the origin of the Cartesian axis (figure 3 ). This phenomenon suggests the existence of a body burden of styrene on Thursday. Such an accumulation of styrene during the workweek was not unexpected according to pharmacokinetic data $(29,30)$ and has also been re- 
ported earlier $(7,14,31)$. We also observed that the intercept of the regression line of the afternoon was nearly $40 \%$ higher than that of the morning regression line. This result suggests an increase in body burden during the day (figures 1 and 2).

Confounding by acetone exposure was unlikely since values equivalent to the exposure levels measured for this compound have not earlier been found to interfere with styrene metabolism or elimination (32).

It was not possible for us to evaluate the effect of alcohol consumption on styrene metabolism. Nevertheless, the current alcohol intake of the workers was fairly moderate ( $<50 \mathrm{~g}$ per day). According to our data, the biological equivalent exposure limit (BEEL) for urinary styrene, corresponding to the current TLV-TWA of the ACGIH (50 ppm), is $727.7 \mathrm{nmol}$. $\mathrm{l}^{-1}$; this limit is close to the BEEL of $768 \mathrm{nmol} \cdot \mathrm{l}^{-1}$ previously proposed $(12,23)$.

A high correlation ( $\mathrm{r}=0.89$ after logarithmic transformation) was observed between the urinary styrene and blood styrene levels of the samples collected a few minutes (10 to $15 \mathrm{~min}$ ) after the end of exposure (figure 4). This finding supports the hypothesis that urinary styrene may be representative of the internal dose of styrene.

Recent data derived from a physiological model also suggest that the concentration of the solvent in the brain, one of the main target organs, is predicted well by urinary levels (33). In consequence, urinary styrene values are likely to represent an index of the active dose of the solvent, rather than a mere exposure index. This possibility is also supported by our preliminary observations on the effects of the solvent on color vision (34). Data obtained in the subgroup of 64 workers were similar to the results of the whole group (table 4). The styrene concentrations of the urine samples collected at the end of the half shifts correlated well with the exposure during the corresponding period of time $(r=0.88$ and 0.86 , respectively, for the morning and afternoon shifts), and the TWA exposure was related to the mean urinary styrene levels $(r=0.88)$. The regression lines were also similar (table 5).

The correlations between airborne styrene and its metabolite concentrations were generally a little lower than for urinary styrene, but of the same order currently reported by others $(8,10,25,26)$. In our end-shift samples we observed no definite improvement in the correlation coefficients when the sum of MA and PGA was used instead of MA only, while PGA alone was less related to the exposure levels. These results are substantially in agreement with those of other studies $(1,26,35)$. Finally, unlike what has been reported by others, the next-morning metabolite values were definitely less related to the external exposure than the end-of-shift values were. This result, together with the similarity of the correlations between the next-morning metabolite levels and the TWA of the morning and afternoon airborne levels of styrene, suggests that there was a relatively low variability in the environmental styrene concentration (or in the individual exposure) during the workday (1).

Our results suggest that urinary styrene represents a good exposure index for styrene. The collection of the samples needs more care than for metabolites, but this care is largely compensated by the specificity and the easily achievable relation to the dose also under field conditions. This index is valid even when only a single half shift can be evaluated.

Nevertheless, it must be stressed that the biological limit that we calculated $\left(728 \mathrm{nmol} \cdot 1^{-1}\right)$ was based on an environmental limit. Factors such as work load, previous exposure, drugs and alcohol consumption, and individual variability have been proved to interfere with the absorption and metabolism of the solvent. Furthermore it is clear that even body burden may affect the BEEL value. For these reasons, to define effective biological exposure limits further, research on effect indices is required. From this point of view, the studies on color vision loss (34) seem to represent a promising beginning.

\section{Acknowledgments}

This work has been supported by the Italian Ministero della Ricerca Scientifica e Tecnologica (Fondi $60 \%)$.

\section{References}

1. Guillemin MP, Berode M. Biological monitoring of styrene: a review. Am Ind Hyg Assoc J 1988;49:497505.

2. American Conference of Governmental Industrial Hygienists (ACGIH). Threshold limit values for chemical substances and physical agents and biological indices for 1991-1992. Cincinnati OH: ACGIH, 1991.

3. Deutsche Forschungsgemeinschaft. BAT: maximum concentrations at the workplace and biological tolerance values for working materials 1991. Weinheim: VCH Verlagsgesellschaft, 1991.

4. Brugnone F, Perbellini L, Gaffuri E, Apostoli P. Biomonitoring of industrial solvent exposure in workers' alveolar air. Int Arch Occup Environ Health 1980;47:245-61.

5. Rappaport SM, Kure E, Petreas M, Ting D, Woodle J. A field method for measuring solvent vapors in exhaled air - application to styrene exposure. Scand J Work Environ Health 1991;17:195-204.

6. Perbellini L, Romeo L, Maranelli G, Zardini G, Alexopoulos C, Brugnone F. Biological monitoring of fluctuating occupational exposure to styrene. Med Lav 1990;81:382 -9.

7. Fields RL, Horstman SW. Biomonitoring of industrial styrene exposure. Am Ind Hyg Assoc J 1979;40:45159.

8. Bartolucci GB, De Rosa E, Gori GP, Chiesura Corona P, Perbellini L, Brugnone F. Biomonitoring of occupational exposure to styrene. Appl Ind Hyg 1986; $1: 125-31$.

9. Lof A, Lundgren E, Byfalt Nordqvist M. Kinetics of styrene in workers from a plastics industry after controlled exposure: a comparison with subjects not previously exposed. $\mathrm{Br} \mathrm{J}$ Ind Med 1986;43:537-43.

10. Apostoli P, Brugnone F, Perbellini C, Cocheo V, Bel- 
lomo LM, Silvestri R. Occupational styrene exposure: environmental and biological monitoring. Am J Ind Med 1983;4:741-54.

11. Cavalleri A, Gobba FM, Imbriani M. Gli indicatori biologici di esposizione a stirene [Biological indices of styrene exposure]. In: Tipolitografia Torriazzi. Strategie per la difesa della salute nel comparto delle vetroresine [Occupational health strategies in the glassreinforced plastics industry]. Parma: Tipolitografia Torriazzi, 1988: 232-45.

12. Imbriani M, Gobba F, Ghittori S, Di Rico R, Piscitelli M, Capodaglio E, et al. Biological monitoring of occupational exposure to styrene. Comparison between urinary mandelic acid concentration and styrene concentration in urine and blood. Appl Ind Hyg 1990; 5:223-8.

13. Pezzagno G, Ghittori S, Imbriani M, Capodaglio E. Eliminazione urinaria di solventi durante esposizioni controllate: la loro concentrazione urinaria come indicatore biologico di esposizione [Urinary excretion of solvents during controlled exposures: urinary concentration as a biological exposure index]. In: Monduzzi. Atti del $48^{\circ}$ Congresso Nazionale della Società Italiana de Medicine del Lavoro e Igine Industriale [Proceedings of the 48th national congress of the Italian Society of Occupational Medicine and Industrial Hygiene]. Bologna: Monduzzi, 1985:511-22.

14. Pezzagno G, Ghittori S, Imbriani M, Capodaglio E. Urinary elimination of styrene in experimental and occupational exposure. Scand J Work Environ Health 1985;11:371-9.

15. Trainia ME, Tancredi F, Bellino M, Ferrari D, Cavariani F, Bocca M. Proposta di un metodo gaschromatografico per la determinazione dei metaboliti urinari dello stirene in lavoratori addetti alla produzione $\mathrm{d}$ manufatti in resine poliestere. [A gas chromatographic method for the determination of the styrene metabolites in workers occupationally exposed to polyesther resins. In: Monduzzi. Atti del $48^{\circ}$ Congresso Nazionale della Società Italiana de Medicine del Lavoro e Igine Industriale [Proceedings of the 47th national congress of the Italian Society of Occupational Medicine and Industrial Hygiene]. Bologna: Monduzzi, 1984: 979-85.

16. Ghittori S, Imbriani M, Pezzagno G, Capodaglio E. The urinary concentration of solvents as a biological indicator of exposure: proposal for the biological equivalent exposure limit for nine solvents. Am Ind Hyg Assoc J 1987;48:786-90.

17. Rosenberg J, Fiserova-Bergerova V, Lowry L. Biological monitoring IV: measurements in urine. Appl Ind Hyg 1989;4:F16-20.

18. Sollenberg J, Bjurström R, Wrangskog K, Vesterberg $\mathrm{O}$. Biological exposure limits estimated from relations between occupational styrene exposure during a workweek and excretion of mandelic and phenylglyoxylic acids in urine. Int Arch Occup Environ Health 1988;60:365-70.

19. Vesterberg O, Sollenberg J, Wrangskog K. Evaluation of determinations made in urine samples: adjustments of mandelic acid concentration using creatinine and density. Ann Am Conf Ind Hyg 1985;12:301-4.

20. Renna E. Il quadro dei rischi igienistici nel comparto P.F.R.V [Hygienic risk assessment in the glass-reinforced plastics industry]. In: Tipolitografia Torriazzi. Strategie per la difesa della salute nel comparto delle vetroresine [Occupational health strategies in the glassreinforced plastics industry]. Parma: Tipolitografia Torriazzi, 1988:7-14.

21. Todd WF, Shulman SA. Control of styrene vapor in a large fiberglass boat manufacturing operation. Am Ind Hyg Assoc J 1984;45:817-25.

22. Lemasters GK, Carson A, Samuels SJ. Occupational styrene exposure for twelve product categories in the reinforced-plastics industry. Am Ind Hyg Assoc J 1985;46:434-41.

23. Ghittori S, Imbriani M. Monitoraggio dell'esposizione professionale a stirene: possibilita' e limiti attuali [Biological monitoring of occupational exposure to styrene]. In: Capodaglio E, Manzo L. ed. Esposizione a stirene: rischi, tossicita' e criteri per il monitoraggio biologico" [Styrene exposure: risks toxicity and criteria for biological monitoring]. Pavia: La Goliardica Pavese, 1990:85-102.

24. Boiteau HL, Pineau A, Limasset JC. Surveillance du risque d'exposition au styrene par le dosage de l'hydrocarbure dans l'air alveolaire et par le dosage de ses metabolites dans les urines [Surveillance of styrene exposure risk by measurement of its metabolites in urine]. J Toxicol Clin Exp 1987;7:93-110.

25. Ikeda M, Koizumi A, Miyasaka M, Watanabe T. Styrene exposure and biological monitoring in FRP production plants. Int Arch Occup Environ Health 1982; 49:325-39.

26. Guillemin MP, Bauer D, Martin B, Marazzi A. Human exposure to styrene: IV. industrial hygiene investigations and biological monitoring in the polyester industry. Int Arch Occup Environ Health 1982;52: $130-50$.

27. Elia VJ, Anderson LA, Macdonald TJ, Carson A, Buncher R, Brooks SM. Determination of urinary mandelic and phenylglyoxylic acids in styrene exposed workers and a control population. Am Ind Hyg Assoc J 1980;41:922-6.

28. Engström K, Härkönen H, Pekari K, Rantanen J. Evaluation of occupational styrene exposure by ambient air and urine analysis. Scand J Work Environ Health 1978;4 suppl 2:121-3.

29. Engström J, Åstrand I, Wigaeus E. Exposure to styrene in a polymerization plant: uptake in the organism and concentration in subcutaneous adipose tissue. Scand J Work Environ Health 1978;4:324-9.

30. Engström J, Bjurström R, Åstrand I, Övrum P. Uptake, distribution and elimination of styrene in man: concentration in subcutaneous adipose tissue. Scand $\mathrm{J}$ Work Environ Health 1978;4:315-23.

31. Gobba F, Di Rico R, Galassi C, Ghittori S, Imbriani M. Studio della cinetica dell'escrezione urinaria di stirene nel corso della settimana lavorativa: implicazioni nella definizione dei valori limite biologici equivalenti (BEEL) per lo stirene urinario [Study of the kinetics of urinary excretion of styrene during the work week: its implications in the definition of biological equivalent exposure limits (BEEL) for urinary styrene]. In: Tipolitografia Torriazz. Strategie per la difesa della salute nel comparto delle vetroresine [Occupational health strategies in the glass-reinforced plastics industry). Parma: Tipolitografia Torriazzi, 1988: 419-24.

32. Wigaeus E, Lof A, Byfalt-Nordqvist M. Uptake, distribution, metabolism and elimination of styrene in man: a comparison between single exposure and coexposure with acetone. Br J Ind Med 1984;41:53946.

33. Droz PO, Wu MM, Cumberland WG. Variability in biological monitoring of organic solvents exposure: II. application of a population physiological model. $\mathrm{Br} \mathrm{J}$ Ind Med 1989;46:547-58.

34. Gobba FM, Galassi C, Ghittori S, Imbriani M, Candela $\mathrm{S}$, Cavalleri A. Acquired dyschromatopsia among styrene exposed workers. J Occup Med 1991;33:761-5.

35. Guillemin MP, Bauer D. Biological monitoring of exposure to styrene by analysis of combined urinary mandelic and phenylglyoxylic acids. Am Ind Hyg Assoc J 1978;39:873-9.

Received for publication: 31 July 1992 